\title{
Penyatuan Pembinaan Pengadilan Pajak
}

\author{
Budi Ispriyarso \\ Fakultas Hukum Universitas Diponegoro \\ Email : budiispriyarso@ymail.com
}

\begin{abstract}
Tax Courts in Indonesia based on Law Number 14 of 2002 concerning Tax Courts. Tax Court, contains many weaknesses. One of its weaknesses is the dualism of building the Tax Court, namely the Ministry of Finance and the Supreme Court. This dualism of formation must be eliminated. The problem is how to eliminate the dualism of coaching. The dualism of coaching the Tax Court, can be eliminated by uniting the coaching of the Tax Court in both the technical coaching of the judiciary and the coaching of the organization, administration and finance under the Supreme Court. The dualism provisions of coaching the tax court in the Tax Court Law must be immediately amended.
\end{abstract}

Keywords: Coaching Dualism, Tax Court, Integration .

\begin{abstract}
Abstrak
Pengadilan Pajak di Indonesia berdasarkan Undang-undang Nomor 14 Tahun 2002 tentang Pengadilan Pajak. Pengadilan Pajak, banyak mengandung kelemahan. Salah satu kelemahannya adalah adanya dualisme pembinaan Pengadilan Pajak, yaitu oleh Kementerian Keuangan dan Mahkamah Agung. Dualisme pembinaan ini harus dihilangkan. Permasahannya adalah bagaimana cara menghilangkan dualisme pembinaan tersebut. Dualisme pembinaan Pengadilan Pajak, dapat dihilangkan dengan cara menyatukan pembinaan Pengadilan Pajak baik pembinaan teknis peradilan maupun pembinaan organisasi, administrasi dan keuangan di bawah Mahkamah Agung. Ketentuan dualisme pembinaan pengadilan pajak dalam UU Pengadilan Pajak harus segera diubah.
\end{abstract}

Kata Kunci : Dualisme Pembinaan, Pengadilan Pajak, Penyatuan.

\section{A. Pendahuluan}

Pengadilan Pajak merupakan salah satu lembaga peradilan yang ada di Indonesia, yang berwenang untuk memeriksa dan memutus atas sengketa pajak. Kompetensi absolut Pengadilan Pajak antara lain adalah memeriksa dan memutus banding dan gugatan pajak. Disamping itu kewenangan lainnya adalah melakukan pengawasan terhadap kuasa hukum yang memberikan bantuan terhadap para pihak yang bersengketa di Pengadilan 
Pajak. ${ }^{1}$ Pengadilan Pajak tidak berwenang untuk memeriksa dan memutus tindak pidana perpajakan, tindak pidana perpajakan menjadi kompetensi dari pengadilan dalam lingkungan peradilan umum.

Dasar hukum Pengadilan Pajak adalah Undang-undang Nomor 14 Tahun 2002 tentang Pengadilan Pajak ( UU Pengadilan Pajak). UU Pengadilan Pajak mencabut dan menyatakan tidak berlaku lagi Undang-Undang Nomor 17 Tahun 1997 tentang Badan Penyelesian Sengketa Pajak (BPSP) ${ }^{2}$. Pengadilan Pajak berdasarkan Undang-Undang Nomor 14 Tahun 2002 mengandung beberapa kelemahan yang perlu dilakukan perbaikan/penyempurnaan. Banyak kritikan yang telah disampaikan oleh para praktisi perpajakan maupun akademisi terhadap Pengadilan Pajak, tetapi sampai saat ini belum dilakukan perubahan terhadap UU Pengadilan Pajak. Namun demikian ada beberapa langkah/usaha pemerintah untuk memperbaiki kelemahan pengadilan Pajak, antara lain penambahan beberapa tempat sidang di luar jakarta, transparansi dalam seleksi penerimaan (rekruitmen) Hakim Pengadilan Pajak, persyaratan pengajuan keberatan dan banding pajak, dan sebagainya. Perubahan /perbaikan lainnya yang telah dilakukan oleh pemerintah, adalah tentang kedudukan Pengadilan Pajak dalam sistem peradilan di Indonesia. Perubahan tersebut adalah memasukan Pengadilan Pajak sebagai Pengadilan Khusus dalam lingkungan Peradilan Tata Usaha Negara. Hal ini seperti yang ditegaskan dalam Undang-Undang Nomor 51 Tahun 2009 tentang Pengadilan Tata Usaha Negara, Undang-Undang Nomor 48 Tahun 2009 tentang Kekuasaan Kehakiman dan Undangundang Nomor 28 Tahun 2007 tentang Ketentuan Umum dan Tatacara Perpajakan , memasukan Pengadilan Pajak sebagai Pengadilan Khusus Pengadilan Tata Usaha Negara. Berdasarkan ketiga undang-undang tersebut, maka kedudukan Pengadilan Pajak sebagai Pengadilan Khusus Pengadilan Tata Usaha Negara. Meskipun Pengadilan Pajak telah dimasukan sebagai Pengadilan Khusus Tata Usaha Negara, namun sampai saat ini, belum ada tindak lanjut atau pengaturan lebih lanjut dimasukannya Pengadilan Pajak sebagai Pengadilan khusus Pengadilan Tata Usaha Negara, sehingga dalam prakteknya saat ini masih berdasarkan UU Nomor 14 Tahun 2002. Demikian juga ketentuan tentang pembinaan Pengadilan Pajak. Pembinaan Pengadilan Pajak, dilakukan oleh Kementerian Keuangan dan Mahkamah Agung (terdapat dualisme pembinaan). Dualisme pembinaan

\footnotetext{
1 Y Sri Pudyatmoko, Pengadilan dan Penyelesaian sengketa di bidang Pajak, Jakarta : PT Gramedia Pustaka Utama, 2005, halaman 72.

${ }^{2}$ Fidel, Tax Law: Proses Beracara di Pengadilan Pajak dan Peradilan Umum, Tangerang : PT Carofin Publishing, 2014, hlm 99.
} 
ini harus dihilangkan, karena tidak sesuai dengan ketentuan UU Kekuasaan Kehakiman. Permasalahannya adalah bagaimana menghilangkan dualisme pembinaan Pengadilan Pajak tersebut?

\section{B. Pembahasan}

\section{B.1. Dualisme Pembinaan Pengadilan Pajak}

Pengadilan Pajak sebagai lembaga peradilan yang berwenang dalam memeriksa dan memutus atas sengketa pajak, berkewajiban untuk memberikan keadilan dan kepastian hukum dalam menyelesaikan sengketa pajak. Keadilan dan kepastian hukum hendaknya berjalan secara seiring, artinya dengan adanya kepastian hukum diharapkan tercapai juga keadilan. Pengadilan Pajak hadir demi memenuhi kebutuhan menciptakan kepastian hukum ( legal certainty) dan keadilan (fairness). ${ }^{3}$

Mengenai pembinaan terhadap Pengadilan Pajak, UU No. 14/2002 tentang Pengadilan Pajak pada bagian keempat tentang pembinaan Pasal 5 ayat (1) menyatakan, "Pembinaan teknis peradilan bagi pengadilan pajak dilakukan oleh Mahkamah Agung" dan Pasal 5 ayat (2) menyatakan, "pembinaan organisasi, administrasi, dan keuangan bagi pengadilan pajak dilakukan oleh Departemen Keuangan”.

Mengenai pembinaan terhadap Pengadilan Pajak dapat dilihat dalam bagan sebagai berikut :

\section{PEMBINAAN PENGADILAN PAJAK}

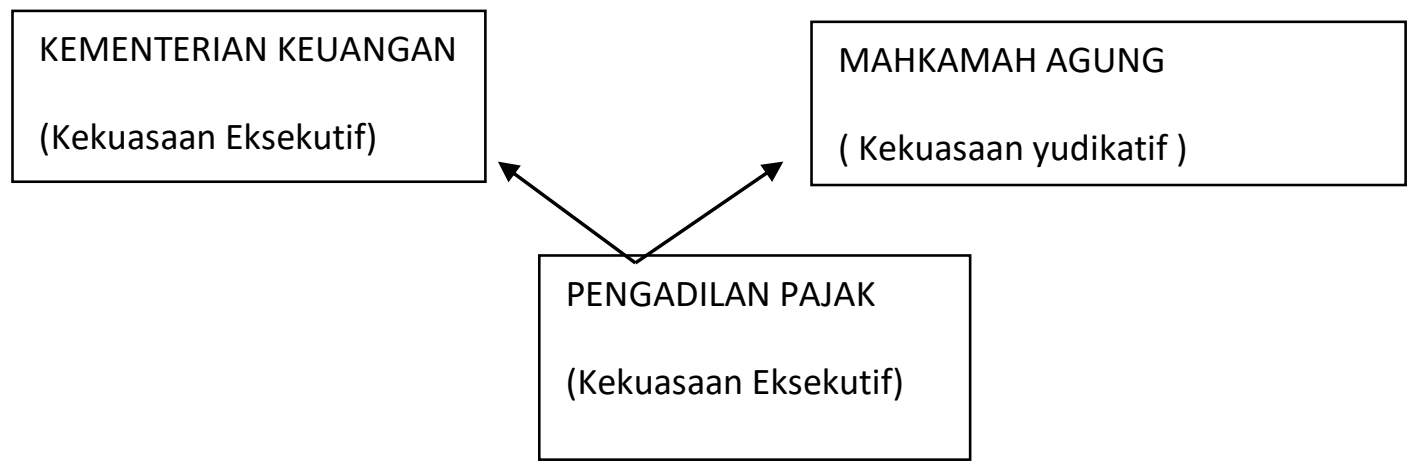

Rumusan Pasal 5 tersebut menunjukan adanya dualisme pembinaan Pengadilan Pajak, yaitu oleh Mahkamah Agung dan Departemen/kKementerian Keuangan. Rumusan ini

\footnotetext{
${ }^{3}$ Tjip Ismail, "Peradilan Pajak dan Kepastian Hukum di Tengah Globalisasi Ekonomi”, Jurnal hukum Ius Quia Iustum,Vol 17 Nomor 2 Tahun 2010, hlm 294.
} 
menunjukkan bahwa pengadilan pajak adalah bentuk pengabungan kekuasaan yudikatif dan eksekutif.

Meninjau "Trias Politika" sebagaimana dikemukakakan oleh Emmanuel Kant maupun Montesquieu dan dikembangkan oleh John Locke melalui ajaran "Separation of Power" bahwa: ${ }^{4}$ There can no be liberty when the legislative and executive power are jointed in the same persons or body of lords because it to be feared that the monarch or body will make tyrannical laws to be administered in tyrannical way. Nor is there any liberty ifthe judicial power is not separated from the legislative and executive power.

Bahwa tidak ada kemerdekaan apabila kekuasaan yudikatif, legislatif, dan eksekutif berada dalam satu tangan atau badan. Apabila kekuasaan-kekuasaan tersebut berada di satu tangan akan menimbulkan suatu "tirani". Disini ditekankan pemisahan kekuasaan antara kekuasaan legislatif dengan eksekutif maupun yudikatif dengan kekuasaan legislatif dan eksekutif.

Berdasarkan ketentuan Pasal 5 ayat (1) dan ayat (2)UU Nomor 14 Tahun 2002 menunjukkan bahwa hakim pengadilan pajak "berkepala dua atau satu kapal bernahkoda dua” yaitu Mahkamah Agung dan Departemen Keuangan.

Pembinaan teknis Pengadilan Pajak oleh Mahkamah Agung merupakan hal yang tepat karena menyangkut kebebasan dalam memeriksa dan memutus sengketa pajak. Di sisi lain, pembinaan organisasi, administrasi dan keuangan oleh Departemen/kementerian keuangan akan menjadi polemik dan akan memunculkan keraguan bagi wajib pajak pencari keadilan. Sehingga dikuatirkan adanya ketergantungan hakim-hakim pengadilan pajak kepada Menteri Keuangan sehingga mempengaruhi setiap keputusan dalam sengketa pajak yang melibatkan pihak yang membinanya dari segi organisasi, administrasi dan keuangan, semua ini dikuatirkan akan berpengaruh terhadap independensi dari putusan sengketa pajak. Apabila ada sengketa pajak maka permohonan atau wajib pajak ada kemungkinan kurang mendapatkan keadilan di pengadilan pajak karena hakim-hakimnya digaji/tunjangan oleh eksekutif (Menteri Keuangan) serta tempat persidangan bertempat di gedung Keuangan (eksekutif) sehingga akan dirasa setiap keputusan tidak cenderung independen. $^{5}$

\footnotetext{
${ }^{4}$ http://www.transparansi.or.id/kajian/reformasi-perpajakan-mewujudkan-pengadilan-pajak-yangberintegritas diakses pada tanggal 6 September 2019

${ }^{5}$ http://www.surabayapagi.com, diakses pada tgl. 3 Oktober 2019.
} 
Dualisme pembinaan terhadap Pengadilan Pajak di dalam Sistem Peradilan di Indonesia, merupakan suatu hal yang janggal dalam Kekuasaan Kehakiman dewasa ini, karena berdasarkan ketentuan Pasal 21 Undang-Undang Nomor 48 Tahun 2009 tentang Kekuasaan Kehakiman, semua urusan Organisasi, administrasi, dan finansial Mahkamah Agung beserta Lingkungan Peradilan yang berada di bawah Mahkamah Agung adalah berada di bawah Mahkamah Agung.

Disamping itu tentang mekanisme pengangkatan hakim Pengadilan Pajak yang melibatkan eksekutif (Menteri Keuangan) sebagaimana yang diatur dalam Pasal 8 ayat (1) dan ayat (2) UU Nomor 14 Tahun 2002 juga bertentangan dengan UU Kekuasaan Kehakiman.

Pasal 8 ayat (1) dan ayat (2) UU Nomor 14 Tahun 2002 tentang Pengadilan Pajak ditentukan bahwa hakim diangkat oleh Presiden dari daftar nama calon yang diusukan Menteri setelah mendapat persetujuan Ketua Mahkamah Agung.

Berdasarkan UU kekuasaan kehakiman, pengangkatan pemberhentian dan mutasi hakim sepenuhnya merupakan kewenangan Kekuasaan Kehakiman dan bukan merupakan kekuasaan eksekutif, baik itu Kementerian Keuangan, termasuk pula Kementerian Hukum dan Hak Asasi Manusia.

Dalam Undang-Undang Nomor 48 Tahun 2009 tentang Kekuasaan Kehakiman Bab IV Pasal 39 ayat (1) menyebutkan bahwa pengawasan tertinggi pada penyelengaraan peradilan pada semua peradilan dibawah Mahkamah Agung dalam menyelengarakan kekuasaan kehakiman dilakukan oleh Mahkamah Agung dan ayat (2) menyebutkan Mahkamah Agung melakukan pengawasan tertinggi terhadap pelaksanaan tugas administrasi dan keuangan.

Bunyi pasal tersebut diatas, dapat diartikan bahwa Mahkamah Agung adalah lembaga pengawasan tertinggi dalam menyelengarakan kekuasaan kehakiman terhadap pelaksanaan tugas administrasi dan keuangan pada semua peradilan yang berada dibawahnya, termasuk pengadilan pajak dilingkungan pengadilan tata usaha negara. Sehingga Pasal 5 ayat (2) Undang-Undang Nomor 14 Tahun 2002 tentang Pengadilan Pajak dan Pasal 8 ayat (1) dan (2) nyata-nyata bertentangan dengan Undang-Undang Nomor 48 Tahun 2009 tentang Kekuasaan kehakiman Pasal 39 ayat (2).

Adanya campurtangan eksekutif/ Menteri Keuangan dalam pengangkatan hakim Pengadilan Pajak bertentangan dengan UU Kekuasaan Kehakiman. Hal ini juga sebagai akibat adanya dualisme pembinaan Pengadilan Pajak. 
Pembinaan organisasi, administrasi dan keuangan Pengadilan Pajak yang dberada di bawah Menteri Keuangan dari aspek keadilan dikuatirkan akan mempengaruhi independensi/kebebasan hakim dalam memberikan putusan.

Mengenai kemandirian hakim ini, karakter pengadilan yang didasarkan pada sistem autopoietik ditekankan bahwa kemandirian pengadilan dan kebebasan hakim tidak dipengaruhi oleh faktor penekan dari luar. Bahan masukan lingkungan setempat tetap penting namun otoritas tetap berada ditangannya. ${ }^{6}$

Demikian juga di Pengadilan Pajak, dalam memberikan putusan, hakim-hakim di Pengadilan pajak tidak boleh mendapat intervensi dari luar baik dari eksekutif maupun pihak lainnya. Oleh karena itu seperti yang disebutkan di atas, maka pembinaan organisasi, administrasi dan keuangan Pengadilan Pajak oleh Kementerian Keuangan dikuatirkan mempengaruhi independensi putusan hakim di Pengadilan Pajak.

Disamping itu juga karena Mahkamah Agung hanya mengawasi secara tidak langsung terhadap hakim-hakim Pengadilan Pajak mengundang kelemahan Pengadilan Pajak khususnya tidak maksimalnya pengawasan hakim-hakim pajak oleh Mahkamah Agung.

Keadaan ini diduga menjadi salah satu sebab yang menghambat independensi para hakim untuk dapat memutus sengketa pajak dengan adil. ${ }^{7}$

\section{B.2. Penyatuan Pembinaaan Pengadilan Pajak}

Berdasarkan uraian di atas, maka dapat diketahui bahwa sampai saat ini, pembinaan Pengadilan Pajak berdasarkan UU Pengadilan Pajak masih terdapat dualisme perpajakan, disatu sisi pembinaan pembinaan teknis peradilan dilakukan oleh Mahkamah Agung dan pembinaan organisasi, administrasi dan keuangan dilakukan oleh Kementerian Keuangan. Dualisme ini bertentangan dengan UU Kekuasaan kehakiman, oleh karena itu dualisme pembinaan ini harus dihilangkan dengan menyatukan kedua pembinaan baik teknis peradilan maupun pembinaan organisasi, administrasi dan keuangan di bawah Mahkamah Agung, seperti lembaga lembaga peradilan lainnya.

Mengenai dualisme pembinaan Pengadilan Pajak, Ketua Muda urusan lingkungan Peradilan Tata Usaha Negara, Paulus Efendi Lotulung menyebut keadaan yang demikian

\footnotetext{
${ }^{6}$ Suteki, "Sinergi Pers Dalam Sistem Autopoietik Pengadilan”, Makalah disampaikan dalam seminar dengan tema : No Trial By The Press, IKAPS, Semarang, 15 Desember 2011, hlm.4

${ }^{7}$ http://www.transparansi.or.id/kajian/reformasi-perpajakan-mewujudkan-pengadilan-pajak-yangberintegritas diakses pada tanggal 6 Pebruari 2019
} 
tersebut, Pengadilan Pajak berdiri di atas dua kaki. Satu kaki berpijak pada Mahkamah Agung, satu lagi berpijak pada Departemen keuangan. Keberadaan Pengadilan Pajak yang berada di dua kaki tersebut berasal dari riwayat Undang-Undang Pengadilan Pajak itu sendiri. Pada Tahun 2004-2009 semua peradilan harus berpuncak pada Mahkamah Agung, sehingga Undang-Undang Pengadilan Pajak harus direvisi. ${ }^{8}$

Pendapat lain dikemukakan oleh M Yahya Harahap yang menyakan bahwa menempatkan badan peradilan di bawah eksekutif, meskipun yang ditempatkan dibawahnya hanyalah organisasi, administrasi dan keuangan, maka sistem seperti ini langsung maupun tidak langsung merupakan simbol pengakuan yuridis bahwa badan peradilan berada di bawah Departemen yang bersangkutan. Simbol tersebut memberikan peringatan kepada hakim akan batas otonomi kebebasan mereka yaitu dalam menjalankan fungsi dan kewenangan peradilan yang berada di bawah Departemen. Oleh karena itu meskipun secara teoritis yang dibina dan diawasi departemen hanyalah organisasi , administrasi maupun keuangan, daya pengaruh simbol yang terkandung didalamnya menimbulkan efek politik dan psikologis yang sangat luas terhadap otonomi kemandirian kebebasan hakim. ${ }^{9}$ Sistem pembinaan yang dualisme dalam Pengadilan Pajak menimbulkan kesulitan dalam menyumbangkan program pengawasan dan pembinaan yang menyeluruh (Komprehensip) dan terpusat (integral). ${ }^{10}$

Syamsuhadi Irsyad menegaskan bahwa organisasi, administrasi dan lembaga kekuasaan kehakiman harus ditangani oleh kekuasaan kehakiman sendiri yaitu oleh badan peradilan. Selama lembaga eksekutif menangani organisasi, administrasi dan keuangan peradilan mengakibatkan beban peradilan tidak berdiri independen terpengaruh oleh kekuasaan eksekutif. ${ }^{11}$

Pengadilan Pajak yang mempunyai dualisme pembinaan tidak sesuai dengan Sistem Peradilan Satu Atap yang telah dilaksanakan pada tanggal 31 Maret 2004. Sistem Peradilan Satu Atap atau kebijakan atap tunggal ( One Roof System ) merupakan persoalan independensi kekuasaan kehakiman. Independensi lembaga peradilan

\footnotetext{
$8 \quad$ www.hukumonline.com/.../posisi-pengadilan-pajak-masih-menjadi-polemik,diakses pada tgl.13 September 2019

${ }^{9}$ Muhammad Djafar Saidi, Perlindungan Hukum Wajib Pajak Dalam Penyelesaian Sengketa Pajak, Jakarta :PT Raja Grafindo,2007, hlm 117.

${ }^{10}$ Loc.cit.

${ }^{11}$ Achmad Mujahidin, Peradilan Satu Atap di Indonesia, Bandung : PT Refika Aditama, 2007, hlm.119.
} 
merupakan kebebasan dan kemandirian lembaga peradilan dalam menjalankan fungsi dan perannya. $^{12}$

Menurut Rusli Muhammad, independensi lembaga peradilan harus menyeluruh tidak terbatas pada salah satu bagian dari lembaga peradilan tetapi harus tersebar kepada seluruh bagian komponen-komponen yang dimiliki yang dimiliki lembaga peradilan. Independensi tidak sekedar pada tingkatan teknisnya saja atau proses peradilannya melainkan juga menyeluruh pada dataran organisasi, administrasi, keuangan dan personilnya. Kekuasaan dan kewenangan Mahkamah Agung secara yuridis formal setelah diberlakukannya peradilan satu atap di Indonesia adalah sebagai sentral pelaksana kekuasaan lembaga peradilan untuk mengurusi, membina dan mengawasi empat lembaga peradilan di bawahnya, yaitu : Peradilan Umum Tingkat Pertama dan Banding, Peradilan Agama Tingkat Pertama dan Banding, Peradilan Tata Usaha Negara Tingkat Pertama dan Banding serta Peradilan Militer Tingkat Pertama, Peradilan Militer Tinggi dan Peradilan Militer Utama dalam hal teknis yudisial maupun dalam hal pembinaan administrasi, organisasi dan finansial serta tugas-tugas pokok lainnya menjadi beban berat bagi institusi Mahkamah Agung. ${ }^{13}$

Terlepas dari ada atau tidaknya pengaruh pembinaan organisasi, administrasi dan keuangan Pengadilan Pajak oleh Kementerian Keuangan, penulis sependapat apabila pembinaan pengadilan pajak sebagaimana diatur UU Nomor 14 Tahun 2002 merupakan dualisme pembinaan terhadap Pengadilan Pajak, oleh karena itu hal ini harus segera diperbaiki demi kepastian hukumnya supaya tidak terjadi kontroversi yuridis antara UU Nomor 14 Tahun 2002 dengan UU Kekuasaan Kehakiman.

Ditinjau dari aspek keadilan adanya pembinaan administrasi,organisasi dan keuangan yang berada di Departemen Keuangan, menimbulkan kekuatiran kemandirian hakim dalam memberikan putusan secara adil, karena dalam sengketa pajak adalah sengketa antara wajib pajak dengan pemerintah (dalam hal ini Kementerian Keuangan khususnya Direktorat Jenderal Pajak dan Direktorat Jenderal Bea dan Cukai ). Di samping itu juga menyebabkan tidak maksimalnya pengawasan oleh Mahkamah Agung terhadap hakim-hakim pajak karena Mahkamah Agung hanya mengawasi secara tidak langsung.

\footnotetext{
${ }^{12}$ Ibid., hlm. 14.

${ }^{13}$ Ibid.,hlm.8.
} 
Perbaikan terhadap sistem pembinaan Pengadilan Pajak dilakukan dengan jalan melakukan revisi terhadap ketentuan Pasal 5 UU Nomor 14 Tahun 2002. Pembinaan teknis maupun pembinaan organisasi, administrasi dan keuangan oleh Mahkamah Agung.

Berdasarkan kepastian hukum, tentunya adanya ketentuan yang baru yang mengatur penyatuan pembinaan Pengadilan Pajak di bawah Mahkamah Agung menghilangkan kontroversi yuridis yang ada sebelumnya.Di samping itu, terpenuhinya kepastian hukum tersebut tidak mengabaikan aspek keadilannya , karena Pembinaan Pengadilan Pajak yang tidak berada di bawah Kementerian Keuangan khususnya untuk organisasi, administrasi dan keuangan menghilangkan kekuatiran hakim untuk bertindak tidak adil. Dalam hal ini lebih menjamin kemandirian hakim. Peralihan pembinaan organisasi, administrasi dan keuangan dari Kementerian Keuangan ke Mahkamah Agung merupakan upaya tegaknya kemandirian lembaga peradilan (Pengadilan Pajak) dari pengaruh kekuasaan eksekutif. Pengadilan Pajak harus merdeka dari pengaruh kekuasaan eksekutif.

Adanya pembinaan pengadilan yang dilakukan oleh Mahkamah Agung yang meliputi pembinaan teknis maupun pembinaan organisasi, administrasi dan keuangan lebih memudahkan pengawasan. Pengawasan disamping secara intern dilakukan oleh Mahkamah Agung, pengawasan secara eksternal dilakukan oleh Komisi Yudisial. Berdasarkan Undang-Undang Nomor 22 Tahun 2004 tentang Komisi Yudisial, Komisi Yudisial mempunyai wewenang untuk menegakan kehormatan dan keluhuran martabat serta menjaga perilaku hakim (Pasal 13). Pengawasan terhadap perilaku hakim Pengadilan Pajak juga merupakan tugas dari Komisi Yudisial sebagai pengawas eksternal sebagaimana dijelaskan pada Penjelasan Umum Undang-Undang Nomor 3 Tahun 2009 tentang Perubahan ke dua atas Undang-Undang Nomor 14 Tahun 1985 tentang Mahkamah Agung. Sedangkan Mahkamah Agung sebagai pengadilan negara tertinggi melakukan pengawasan tertinggi terhadap badan peradilan di bawahnya (merupakan pengawasan internal). Pasal 32 Undang-Undang Nomor 32 Tahun 2009 menyatakan bahwa Mahkamah Agung sebagai pengadilan negara tertinggi negara melakukan pengawasan tertinggi terhadap penyelenggaraan pada semua badan peradilan yang berada di bawahnya dalam menyelenggarakan kekuasaan kehakiman. Selain itu Mahkamah Agung juga melakukan pengawasan tertinggi terhadap pelaksanaan tugas administrasi dan keuangan. Pengawasan tersebut termasuk pengawasan terhadap Pengadilan Pajak yang berada di bawah Mahkamah Agung. 
Upaya pembaruan pengadilan pajak khususnya tentang pembinaan pengadilan pajak dengan menyatukan pembinaan peradilan merupakan salah satu langkah mewujudkan pengadilan pajak yang mencerminkan kepastian hukum dan keadilan.

Setelah adanya penyempurnaan/perbaikan kedudukan Pengadilan Pajak sebagai Pengadilan Khusus di lingkungan Peradilan Tata Usaha Negara seperti yang diatur dalam UU PTUN, UU Kehakiman dan UU KUP, maka beberapa kelemahan Pengadilan Pajak seperti yang diatur dalam UU Nomor 14 Tahun 2002 harus segera diperbaiki. Salah satu perbaikan yang perlu segera dilakukan adalah penyatuan pembinaan Pengadilan Pajak, di bawah Mahkamah Agung.

\section{Simpulan}

Bedasarkan uraian di atas dapat disimpulkan bahwa Pembinaan Pengadilan Pajak sampai sekarang masih terjadi dualisme pembinaan, pembinaan administrasi, organisasi dan keuangan dilakukan oleh Kementerian Keuangan, sedangkan pembinaan teknis peradilan oleh Mahkamah Agung. Dualisme pembinaan terhadap Pengadilan Pajak dihilangkan dengan cara menyatukan pembinaan Pengadilan Pajak baik pembinaan administrasi, organisasi dan Keuangan maupun pembinaan teknis peradilan dilakukan oleh Mahkamah Agung. Ketentuan dualisme pembinaan Pengadilan Pajak yang terdapat dalam UU Pengadilan Pajak harus segera diubah.

\section{Daftar Pustaka}

Ismail,Tjip "Peradilan Pajak dan Kepastian Hukum di Tengah Globalisasi Ekonomi", Jurnal hukum Ius Quia Iustum,Vol 17 Nomor 2 Tahun 2010

Mujahidin ,Achmad, Peradilan Satu Atap di Indonesia, Bandung : PT Refika Aditama, 2007

Pudyatmoko, Y Sri, Pengadilan dan Penyelesaian sengketa di bidang Pajak, Jakarta : PT Gramedia Pustaka Utama, 2005

Saidi , Muhammad Jafar, Perlindungan Hukum Wajib Pajak Dalam Penyelesaian Sengketa Pajak, Jakarta :PT Raja Grafindo,2007.

Suteki, "Sinergi Pers Dalam Sistem Autopoietik Pengadilan", Makalah disampaikan dalam seminar dengan tema : No Trial By The Press, IKAPS, Semarang, 15 Desember 2011

www.hukumonline.com/.../posisi-pengadilan-pajak-masih-menjadi-polemik http://www.transparansi.or.id/kajian/reformasi-perpajakan-mewujudkan-pengadilanpajak-yang-berintegritas

Undang-Undang Dasar Negara Republik Indonesia tahun 1945

Undang-Undang Nomor 48 Tahun 2009 tentang kekuasaan Kehakiman 
Undang-Undang Nomor 3 Tahun 2009 tentang Perubahan kedua Atas Undang Undang Nomor 14 Tahun 1985 tentang Mahkamah Agung

Undang-Undang Nomor 28 Tahun 2007 Tentang Perubahan Ketiga Atas UndangUndang Nomor 6 Tahun 1983 tentang ketentuan Umum dan Tatacara Perpajakan

Undang-Undang Nomor 16 Tahun 2009 tentang Penetapan Peraturan Pemerintah Pengganti Undang-Undang Nomor 5 Tahun 2008 Tentang Perubahan Keempat Atas Undang-Undang Nomor 6 Tahun 1983 Tentang Ketentuan Umum Dan Tata Cara Perpajakan Menjadi Undang-Undang

Undang-Undang Nomor 51 Tahun 2009 tentang Perubahan Kedua atas UndangUndang Nomor 5 Tahun 1986 tentang Peradilan Tata Usaha Negara

Undang-Undang Nomor 12 Tahun 2011 tentang Pembentukan Peraturan PerundangUndangan.

Undang-Undang Nomor 14 Tahun 2002 tentang Pengadilan Pajak. 